\title{
Interleukin-1 and lipid metabolism in the rat
}

\author{
Josep M. ARGILÉS,* Francisco J. LOPEZ-SORIANO,* Rhys D. EVANS and Dermot H. WILLIAMSON† \\ Metabolic Research Laboratory, Nuffield Department of Clinical Medicine, Radcliffe Infirmary, Woodstock Road, \\ Oxford OX2 6HE, U.K.
}

\begin{abstract}
Intravenous administration of a single dose $(20 \mu \mathrm{g})$ of recombinant interleukin-1- $\beta$ to virgin, lactating and litter-removed rats rapidly decreased intestinal lipid absorption in all groups. In vivo, oxidation of $\left[{ }^{14} \mathrm{C}\right]$ triolein to ${ }^{14} \mathrm{CO}_{2}$ was also significantly decreased by interleukin-1. In addition, the cytokine decreased $\left[{ }^{14} \mathrm{C}\right]$ lipid accumulation in the mammary gland of lactating rats and in the adipose tissue of virgin and litterremoved rats. The decrease in lipid uptake in the interleukin-treated rats was accompanied by hypertriglyceridaemia ; however, there was no significant decrease in tissue lipoprotein lipase activity, except in heart from lactating rats. In contrast, interleukin-1 administration had no effect on lipogenesis in liver, white or brown adipose tissue of virgin rats fed on glucose. These results suggest that interleukin-1 profoundly affects lipid metabolism by delaying intestinal absorption and decreasing tissue uptake.
\end{abstract}

\section{INTRODUCTION}

Interleukin-1, primarily produced from phagocytic cells, is a polypeptide capable of mediating the host's responses to infection and inflammation (see Dinarello, 1984). The physiological and metabolic effects that follow interleukin- 1 administration to experimental animals are varied and include fever (Dinarello \& Wolff, 1982), neutrophil activation (Kampschmidt, 1984), B- and T-cell activation (Falkoff et al., 1983; Mizel, 1982), enhanced liver protein synthesis (Pepys \& Baltz, 1983) and amino acid release from skeletal muscle (Baracos et al., 1983). Studies in vitro have also shown the ability of interleukin-1 to decrease lipoprotein lipase activity in cultured 3T3-L1 adipocytes by inhibiting the synthesis of the enzyme (Price et al., 1986). Little is known of the effects of interleukin-1 in vivo on lipid metabolism. We have therefore studied the effects of acute interleukin-1 administration on the utilization of dietary lipid $\left(\left[{ }^{14} \mathrm{C}\right]\right.$ triolein $)$ in virgin, lactating and litter-removed rats. Lactation was chosen as a model because it involves important changes in partitioning of dietary fat between mammary gland and adipose tissue (see Williamson, 1980; Vernon \& Flint, 1983; Scow \& Chernick, 1987). Lactation decreases lipogenesis (Agius et al., 1979), lipoprotein lipase (Hamosh et al., 1970; Flint et al., 1981) and lipid uptake (Oller do Nascimento \& Williamson, 1986) in adipose tissue, but enhances metabolic activity in the mammary gland (Williamson, 1986). The lactating mammary gland has increased rates of lipogenesis, increased lipoprotein lipase activity and lipid uptake. These tissue-specific changes in lipid metabolism are rapidly reversed on removal of the suckling litter (Williamson, 1980; Vernon \& Flint, 1983; Oller do Nascimento \& Williamson, 1986; Scow \& Chernick, 1987).

\section{EXPERIMENTAL}

\section{Animals}

Female Wistar rats were fed ad libitum on a chow diet consisting of (by wt.) $52 \%$ carbohydrate, $21 \%$ protein and $4 \%$ fat (the residue was non-digestible material; Special Diet Services, Witham, Essex, U.K.) with free access to drinking water, and were maintained at an ambient temperature of $22 \pm 2{ }^{\circ} \mathrm{C}$ with a $12 \mathrm{~h}$-light $/ 12 \mathrm{~h}$ dark cycle (lights on from 07:00 h). Three groups of rats were studied: Group 1 were virgin females $(212 \pm 5.0 \mathrm{~g})$, Group 2 were lactating rats $(285 \pm 15 \mathrm{~g})$ with eight to eleven pups used 10-13 days post partum, and Group 3 were lactating rats $(315 \pm 10 \mathrm{~g})$ whose litters had been prematurely removed for $24 \mathrm{~h}, 10-13$ days post partum.

\section{Biochemicals}

All enzymes and coenzymes were purchased from Boehringer Corp. (London) Ltd., Lewes, Sussex, U.K. $\left[1-{ }^{14} \mathrm{C}\right]$ Triolein (glycerol tri $\left[1-{ }^{14} \mathrm{C}\right]$ oleate) and glycerol tri $\left[9,10(n)-{ }^{3} \mathrm{H}\right]$ oleate were obtained from Amersham International, Amersham, Bucks., U.K. Human recombinant interleukin-1- $\beta$ was kindly given by Eli Lilly and Co., Indianapolis, IN, U.S.A.

\section{Measurement of lipid oxidation and tissue lipid accumulation}

At $1 \mathrm{~h}$ after the intravenous administration (tail vein) of a single dose of interleukin-1- $\beta(20 \mu \mathrm{g}$ in $0.5 \mathrm{ml}$ of $0.9 \% \mathrm{NaCl}$ ) or saline, the metabolic fate of an orally administered $\left[{ }^{14} \mathrm{C}\right]$ lipid load was examined as described by Oller do Nascimento \& Williamson (1986). About $0.5 \mathrm{~g}(0.82 \mu \mathrm{Ci})$ of $\left[1-{ }^{14} \mathrm{C}\right]$ triolein per rat was given enterally by gastric intubation, without anaesthetic but with minimal stress to the animal. Expired $\mathrm{CO}_{2}$ was then collected hourly for $5 \mathrm{~h}$ by absorption in Lumasorb (May \& Baker, Dagenham, Essex, U.K.), and the rate of ${ }^{14} \mathrm{CO}_{2}$ production was estimated by counting radioactivity in a sample of the Lumasorb. After the $5 \mathrm{~h}$ collection period, the animal was killed. Arterial blood was collected in a heparinized syringe. The gastrointestinal tract (plus contents) was homogenized in $150 \mathrm{ml}$ of $3 \%(\mathrm{w} / \mathrm{v}) \mathrm{HClO}_{4}$. Duplicate samples were taken of liver, perigenital and perirenal white adipose tissue, mammary gland and interscapular brown adipose tissue (single sample). Carcass (minus liver, mammary

* Present address: Departament de Bioquimica i Fisiologia, Facultat de Biologia, Universitat de Barcelona, Diagonal 645, 08071 Barcelona, Spain.

$\dagger$ To whom correspondence and reprint requests should be addressed. 
gland and intestinal tract) was treated as previously described (Oller do Nascimento \& Williamson, 1988). Tissues were saponified and the lipid was extracted (Stansbie et al., 1976). The amount of lipid extracted from the carcass was determined gravimetrically. The extracted fatty acids were dissolved in $10 \mathrm{ml}$ of scintillation fluid (Optiphase 'Safe'; LKB) for measurement of radioactivity and hence determination of $\left[{ }^{14} \mathrm{C}\right]$ lipid accumulation. $\left[1-{ }^{14} \mathrm{C}\right]$ Triolein absorption was calculated by subtracting total gastrointestinal radioactivity from that administered.

\section{Lipoprotein lipase}

Perigenital-adipose-tissue, heart and mammary-gland lipoprotein lipase activities were estimated by a modification of the technique of Nilsson-Ehle \& Ekman (1977). Tissue samples were dried to a powder with acetone/diethyl ether, and then resolubilized and used in an assay system containing $\left[{ }^{3} \mathrm{H}\right]$ triolein as substrate; ${ }^{3} \mathrm{H}$ labelled fatty acids released after a $60 \mathrm{~min}$ incubation period were extracted and determined by the method of Nilsson-Ehle \& Schotz (1976). Lipoprotein lipase activity is expressed as nmol of fatty acid released/min per $\mathrm{mg}$ of acetone-dried powder. Post-heparin plasma lipolytic activity was measured in control and interleukin-treated virgin rats $20 \mathrm{~min}$ after intravenous injection (femoral vein) of 1000 units of heparin $/ \mathrm{kg}$ body wt., in accordance with the procedure of Kuwajima et al. (1988).

\section{Measurement of lipogenesis}

Lipogenesis in vivo was determined $5 \mathrm{~h}$ after the administration of either saline or interleukin-1. An intragastric glucose $(4 \mathrm{mmol})$ load to stimulate lipogenesis (Agius \& Williamson, 1980) was given $90 \mathrm{~min}$ before death of the rat. Lipogenic rate in vivo was determined with ${ }^{3} \mathrm{H}_{2} \mathrm{O}$ as previously described (Robinson et al., 1978). At $1 \mathrm{~h}$ before being killed, animals were injected with $0.3 \mathrm{ml}(3.0 \mathrm{mCi})$ of ${ }^{3} \mathrm{H}_{2} \mathrm{O}$ intraperitoneally; $5 \mathrm{~min}$ before death the animals were anaesthetized with pentobarbital $(60 \mathrm{mg} / \mathrm{kg}$ body wt.). Tissues were saponified and fatty acids extracted by the method of Stansbie et al. (1976). The amount of glucose load absorbed was measured as described by Mercer \& Williamson (1987).

\section{Blood metabolites and plasma insulin}

Whole-blood glucose was determined by the method of Slein (1963) and lactate by the method of Hohorst (1963). Plasma triacylglycerol was measured by the method of Eggstein \& Kreutz (1966). Plasma glycerol was measured by the method of Garland \& Randle (1962), and plasma non-esterified fatty acids were measured with an enzymic colorimetric method (Wako Chemicals G.m.b.H, Neuss, West Germany). Plasma insulin was determined by radioimmunoassay with a rat insulin standard (Albano et al., 1972).

\section{RESULTS AND DISCUSSION}

Absorption, oxidation and tissue accumulation of an oral $\left[{ }^{14}\right.$ C]triolein load

Treatment with interleukin- 1 decreased (by $40-50 \%$ ) intestinal absorption of lipid in all the experimental groups (Table 1). Results of $\left[1-{ }^{14} \mathrm{C}\right]$ triolein disposal have therefore been expressed as \% of absorbed dose.

Administration of interleukin-1 decreased oxidation of $\left[{ }^{14} \mathrm{C}\right]$ lipid to ${ }^{14} \mathrm{CO}_{2}$ (2-3-fold), over a $5 \mathrm{~h}$ period, in all groups (Table 1). As expected, ${ }^{14} \mathrm{CO}_{2}$ production was higher in the control virgin than in the control lactating and litter-removed rats (Table 1; Oller do Nascimento \& Williamson, 1986).

Interleukin-1 treatment decreased lipid accumulation in most of the tissues studied (Table 1); however, the effects differed between tissues and between the experimental groups. In both virgin and litter-removed rats, $\left[{ }^{14} \mathrm{C}\right]$ lipid accumulation was significantly decreased in carcass and adipose tissue (white and brown) in the interleukin-1-treated group. In contrast, lactating rats showed a marked decrease of $\left[{ }^{14} \mathrm{C}\right]$ triolein deposition in mammary gland, with no significant changes in $\left[{ }^{14} \mathrm{C}\right]$ lipid accumulation in carcass or adipose tissue (brown or white) (Table 1). Pup lipid accumulation was also significantly decreased by interleukin-1. It seems that this cytokine can affect lactation via inhibition of the uptake of circulating dietary lipid by mammary gland. Interleukin-1 treatment increased the accumulation of saponified $\left[{ }^{14} \mathrm{C}\right]$ lipid in the liver of the litter-removed group. Accumulation in the non-saponified (sterol) lipids was low and not altered by interleukin-1. The overall effect of interleukin-1 on dietary lipid disposal is particularly marked if total mammary-gland and adiposetissue accumulation are estimated (Table 1). In lactating rats, interleukin- 1 caused a significant decrease $(45 \%)$ in total mammary-gland accumulation, whereas in litterremoved rats, the effect of the cytokine was on adipose tissue ( $70 \%$ decrease) (Table 1$)$.

\section{Gastrointestinal partitioning of the $\left[{ }^{14} \mathrm{C}\right]$ lipid}

To see if the striking effects of interleukin-1 on intestinal lipid absorption were related to altered gastrointestinal transit, the distribution of the $\left[{ }^{14} \mathrm{C}\right]$ triolein between the stomach and the intestine was studied (Table 2 ). In all control groups, $5 \mathrm{~h}$ after the administration of the tracer, most of the residual label $(60-80 \%)$ was already in the intestine, having left the stomach. Interleukin-1 reversed this pattern of distribution: most of the label was found in the stomach $(58-70 \%)$ of the treated animals. Similar results were found when the gastric and intestinal contents of glucose and lactate were measured after an oral load of glucuse $(4 \mathrm{mmol})$ to virgin rats. Absorption of glucose from the intestinal tract was decreased from $74.3 \% \pm 5.9$ (control group; $n=5$ ) to $40.2 \% \pm 3.9$ (treated group; $n=5$ ). The distribution of glucose and lactate in the gastrointestinal tract was affected by interleukin-1 in a similar way to that of triolein (J. M. Argilés \& F. J. Lopez-Soriano, unpublished work). It seems probable that the action of the cytokine upon absorption is to slow gastric transit, which, in turn, significantly affects nutrient uptake. Others have shown that another cytokine, tumour necrosis factor, inhibits gastric emptying (Patton et al., 1987), but as far as we are aware this has not been reported for interleukin-1.

\section{Lipoprotein lipase and plasma triacylglycerols}

To examine whether the decreased tissue accumulation of dietary $\left[{ }^{14} \mathrm{C}\right]$ lipid after interleukin-1 treatment was due to a decrease of lipoprotein lipase activity, the enzyme responsible for the hydrolysis of plasma triacylglycerols (see Robinson, 1970), the activity was measured in white adipose tissue, mammary gland and heart (Table 3). Although there was a tendency for interleukin-1 to 
Table 1. Effects of interleukin-1 on the absorption and metabolic fate of orally administered $\left|1-{ }^{14} \mathrm{C}\right|$ triolein in fed virgin, lactating and litter-removed rats

For full details see the Experimental section. ${ }^{14} \mathrm{CO}_{2}$ production was calculated during the course of the $5 \mathrm{~h}$ after triolein administration. The results are mean values \pm S.E.M. for five observations. Total estimated adipose-tissue accumulation was calculated assuming that all carcass fat corresponded to adipose tissue. Interleukin-1-treated values that are significantly different by Student's $t$ test from their corresponding control values are indicated by: ${ }^{*} P<0.05,{ }^{* *} P<0.01,{ }^{* * *} P<0.001$.

\begin{tabular}{|c|c|c|c|c|}
\hline \multirow[b]{2}{*}{ Measurement } & \multirow[b]{2}{*}{ Treatment } & \multicolumn{3}{|c|}{ State of rats } \\
\hline & & Virgin & Lactating & Litter-removed \\
\hline Absorption $(\%$ of administered dose $)$ & $\begin{array}{l}\text { Control } \\
\text { Interleukin-1 }\end{array}$ & $\begin{array}{l}76.5 \pm 2.2 \\
31.8 \pm 4.0^{* * *}\end{array}$ & $\begin{array}{l}82.1 \pm 4.8 \\
36.3 \pm 1.2 * * *\end{array}$ & $\begin{array}{l}83.0 \pm 1.8 \\
41.8 \pm 4.9^{* * *}\end{array}$ \\
\hline${ }^{14} \mathrm{CO}_{2}$ production ( $\%$ of absorbed dose) & $\begin{array}{l}\text { Control } \\
\text { Interleukin-1 }\end{array}$ & $\begin{array}{l}33.4 \pm 4.15 \\
10.8 \pm 3.07 * *\end{array}$ & $\begin{array}{l}13.1 \pm 2.62 \\
4.64 \pm 1.07^{*}\end{array}$ & $\begin{array}{l}10.0 \pm 1.70 \\
6.38 \pm 0.72^{*}\end{array}$ \\
\hline $\begin{array}{l}\text { Tissue accumulation }(\% \text { of absorbed dos } \\
\text { Carcass (mother) }\end{array}$ & $\begin{array}{l}\text { Control } \\
\text { Interleukin-1 }\end{array}$ & $\begin{array}{l}0.17 \pm 0.02 \\
0.08 \pm 0.02 *\end{array}$ & $\begin{array}{l}0.04 \pm 0.01 \\
0.08 \pm 0.03\end{array}$ & $\begin{array}{l}0.24 \pm 0.01 \\
0.12 \pm 0.01^{* * *}\end{array}$ \\
\hline Carcass (pups) & $\begin{array}{l}\text { Control } \\
\text { Interleukin-1 }\end{array}$ & $\begin{array}{l}- \\
-\end{array}$ & $\begin{array}{l}0.06 \pm 0.02 \\
0.01 \pm 0.003 *\end{array}$ & $\begin{array}{l}- \\
-\end{array}$ \\
\hline Liver (saponified) & $\begin{array}{l}\text { Control } \\
\text { Interleukin-1 }\end{array}$ & $\begin{array}{l}0.63 \pm 0.05 \\
0.47 \pm 0.12\end{array}$ & $\begin{array}{l}0.23 \pm 0.06 \\
0.34 \pm 0.06\end{array}$ & $\begin{array}{l}0.47 \pm 0.03 \\
0.69 \pm 0.05^{* *}\end{array}$ \\
\hline Liver (non-saponified) & $\begin{array}{l}\text { Control } \\
\text { Interleukin-1 }\end{array}$ & $\begin{array}{l}0.06 \pm 0.006 \\
0.04 \pm 0.009\end{array}$ & $\begin{array}{l}0.03 \pm 0.006 \\
0.03 \pm 0.006\end{array}$ & $\begin{array}{l}0.06 \pm 0.01 \\
0.06 \pm 0.006\end{array}$ \\
\hline Mammary gland & $\begin{array}{l}\text { Control } \\
\text { Interleukin-1 }\end{array}$ & $\begin{array}{l}- \\
-\end{array}$ & $\begin{array}{l}2.32 \pm 0.12 \\
1.34 \pm 0.14 * * *\end{array}$ & $\begin{array}{l}0.10 \pm 0.01 \\
0.08 \pm 0.02\end{array}$ \\
\hline Brown adipose tissue & $\begin{array}{l}\text { Control } \\
\text { Interleukin-1 }\end{array}$ & $\begin{array}{l}5.59 \pm 1.46 \\
1.88 \pm 0.58 *\end{array}$ & $\begin{array}{l}0.20 \pm 0.09 \\
0.17 \pm 0.06\end{array}$ & $\begin{array}{l}4.33 \pm 0.85 \\
1.47 \pm 0.36^{*}\end{array}$ \\
\hline Perirenal white adipose tissue & $\begin{array}{l}\text { Control } \\
\text { Interleukin-1 }\end{array}$ & $\begin{array}{l}0.71 \pm 0.18 \\
0.12 \pm 0.03^{*}\end{array}$ & $\begin{array}{l}0.04 \pm 0.006 \\
0.05 \pm 0.01\end{array}$ & $\begin{array}{l}2.41 \pm 0.52 \\
0.74 \pm 0.08^{*}\end{array}$ \\
\hline Perigenital white adipose tissue & $\begin{array}{l}\text { Control } \\
\text { Interleukin-1 }\end{array}$ & $\begin{array}{l}0.62 \pm 0.16 \\
0.14 \pm 0.04^{*}\end{array}$ & $\begin{array}{l}0.03 \pm 0.007 \\
0.04 \pm 0.009\end{array}$ & $\begin{array}{l}1.96 \pm 0.35 \\
0.87 \pm 0.23^{*}\end{array}$ \\
\hline Plasma & $\begin{array}{l}\text { Control } \\
\text { Interleukin-1 }\end{array}$ & $\begin{array}{l}0.08 \pm 0.005 \\
0.14 \pm 0.03\end{array}$ & $\begin{array}{l}0.07 \pm 0.01 \\
0.17 \pm 0.04^{*}\end{array}$ & $\begin{array}{l}0.12 \pm 0.01 \\
0.70 \pm 0.18^{*}\end{array}$ \\
\hline $\begin{array}{l}\text { Total estimated white-adipose-tissue } \\
\text { accumulation }\end{array}$ & $\begin{array}{l}\text { Control } \\
\text { Interleukin-1 }\end{array}$ & $\begin{array}{r}17.4 \pm 5.97 \\
3.8 \pm 1.26\end{array}$ & $\begin{array}{l}0.53 \pm 0.14 \\
0.56 \pm 0.14\end{array}$ & $\begin{array}{l}46.2 \pm 7.19 \\
13.4 \pm 2.05^{* *}\end{array}$ \\
\hline $\begin{array}{l}\text { Total estimated mammary-gland } \\
\text { accumulation }\end{array}$ & $\begin{array}{l}\text { Control } \\
\text { Interleukin-1 }\end{array}$ & $\begin{array}{l}- \\
-\end{array}$ & $\begin{array}{l}37.6 \pm 3.21 \\
20.8 \pm 1.87^{* *}\end{array}$ & $\begin{array}{l}2.9 \pm 0.57 \\
2.2 \pm 0.26\end{array}$ \\
\hline
\end{tabular}

Table 2. Effects of interleukin-1 on the distribution of ${ }^{14} \mathrm{C} \mid$ triolein in the gastrointestinal tract of virgin, lactating and litter-removed rats

Deproteinized samples of stomach and intestine of the different groups of rats, $5 \mathrm{~h}$ after the administration of the tracer, were used to assess partition of the residual lipid fraction. The results, expressed as $\%$ of total residual lipid, are mean values of two or three rats in each group. For full details see the Experimental section.

\begin{tabular}{|c|c|c|c|c|c|c|}
\hline \multirow[b]{3}{*}{ Tissue } & \multicolumn{6}{|c|}{ State of rats } \\
\hline & \multicolumn{2}{|c|}{ Virgin } & \multicolumn{2}{|c|}{ Lactating } & \multicolumn{2}{|c|}{ Litter-removed } \\
\hline & Control & Interleukin-1 & Control & Interleukin-1 & Control & Interleukin-1 \\
\hline Stomach & 19.9 & 64.7 & 20.2 & 58.6 & 39.3 & 69.2 \\
\hline Intestine & 80.1 & 35.3 & 79.8 & 41.4 & 60.7 & 30.8 \\
\hline
\end{tabular}

decrease the activity in white adipose tissue of virgin and litter-removed rats and lactating mammary gland, the changes are not significant. The only significant decrease was in heart of the lactating group. This lack of effect of interleukin-1 on lipoprotein lipase activity in the present experiments is in contrast with the pronounced inhibition in 3T3 Ll adipocytes in vitro (Price et al., 1986). Despite this, there was marked hypertriglyceridaemia in all interleukin-treated groups (Table 3). Thus the decreased lipid accumulation in the tissues, together with the increased plasma triacylglycerol, is evidence of impairment of functional lipoprotein lipase activity, although 
Table 3. Effects of interleukin-1 on plasma triacylglycerol, glycerol and non-esterified fatty acid concentrations and tissue lipoprotein lipase activity in fed virgin, lactating and litter-removed rats

For full details see the Experimental section. The results are mean values \pm S.E.M. for five observations except where otherwise stated. Lipoprotein lipase activity is expressed as nmol of fatty acid released/min per $\mathrm{mg}$ of acetone-dried powder. Values that are significantly different by Student's $t$ test from control values are indicated by: ${ }^{*} P<0.05,{ }^{* *} P<0.01,{ }^{* * *} P<0.001$.

\begin{tabular}{|c|c|c|c|c|}
\hline \multirow[b]{2}{*}{ Measurement } & \multirow[b]{2}{*}{ Treatment } & \multicolumn{3}{|c|}{ State of rats } \\
\hline & & Virgin & Lactating & Litter-removed \\
\hline \multicolumn{5}{|l|}{ Lipoprotein lipase activity } \\
\hline White adipose tissue & $\begin{array}{l}\text { Control } \\
\text { Interleukin-1 }\end{array}$ & $\begin{array}{l}1.150 \pm 0.172 \\
0.704 \pm 0.199\end{array}$ & $\begin{array}{l}0.301 \pm 0.041 \\
0.260 \pm 0.025\end{array}$ & $\begin{array}{l}0.985 \pm 0.138 \\
0.795 \pm 0.105\end{array}$ \\
\hline Mammary gland & $\begin{array}{l}\text { Control } \\
\text { Interleukin-1 }\end{array}$ & $\begin{array}{l}- \\
-\end{array}$ & $\begin{array}{l}0.524 \pm 0.102 \\
0.306 \pm 0.037\end{array}$ & $\begin{array}{l}0.032 \pm 0.006 \\
0.032 \pm 0.014\end{array}$ \\
\hline Heart & $\begin{array}{l}\text { Control } \\
\text { Interleukin-1 }\end{array}$ & $\begin{array}{l}0.437 \pm 0.056 \\
0.385 \pm 0.041\end{array}$ & $\begin{array}{l}0.340 \pm 0.080 \\
0.137 \pm 0.022 *\end{array}$ & $\begin{array}{l}0.219 \pm 0.074 \\
0.180 \pm 0.043\end{array}$ \\
\hline Plasma triacylglycerol $(\mathrm{mg} / 100 \mathrm{ml})$ & $\begin{array}{l}\text { Control } \\
\text { Interleukin-1 }\end{array}$ & $\begin{array}{l}51.9 \pm 3.5 \\
99.2 \pm 14.0^{* *}\end{array}$ & $\begin{array}{c}62.1 \pm 6.7 \\
264.4 \pm 32.2^{* * *}\end{array}$ & $\begin{array}{l}176.6 \pm 32.8 \\
801.5 \pm 163.5^{*}\end{array}$ \\
\hline Plasma glycerol (nmol/ml) & $\begin{array}{l}\text { Control } \\
\text { Interleukin-1 }\end{array}$ & $\begin{array}{l}168 \pm 13(4) \\
228 \pm 25(4)\end{array}$ & $\begin{array}{l}172 \pm 37(4) \\
212 \pm 25(3)\end{array}$ & $\begin{array}{l}292 \pm 58(3) \\
235 ; 452(2)\end{array}$ \\
\hline Plasma non-esterified fatty acids (nequiv./ml) & $\begin{array}{l}\text { Control } \\
\text { Interleukin-1 }\end{array}$ & $\begin{array}{l}552 \pm 60 \\
816 \pm 113\end{array}$ & $\begin{array}{l}711 \pm 139(4) \\
934 \pm 117\end{array}$ & $\begin{array}{l}1390 \pm 276(4) \\
2626 \pm 395(4)^{*}\end{array}$ \\
\hline
\end{tabular}

the hypertriglyceridaemia may also in part be due to increased adipose tissue lipolysis as occurs in 3T3 L1 adipocytes (Price et al., 1986) and subsequent increased secretion of very-low-density lipoproteins from the liver. Further support for these views is that plasma postheparin lipolytic activity, an index of heparin-releasable lipases, was significantly decreased $(P<0.05)$ in interleukin-treated virgin rats $[341 \pm 66(4) \mathrm{nmol}$ of fatty acid released $/ \mathrm{min}$ per $\mathrm{ml}$ of plasma, versus $523 \pm 10(4)$ for control virgin rats]. Despite this evidence for impairment of functional lipoprotein lipase activity, plasma glycerol and plasma non-esterified fatty acids were not decreased by interleukin treatment (Table 3) and tended to be higher than the control values. As the two major potential sources of plasma glycerol and non-esterified fatty acids are the activities of lipoprotein lipase or hormone-sensitive triacylglycerol lipase in adipose tissue, the present evidence supports the view that there is increased lipolysis in adipose tissue in interleukin-treated rats.

\section{Tissue lipogenesis in vivo}

Interleukin-1 has no acute effect on the synthesis of fatty acids de novo as measured by $\left[{ }^{14} \mathrm{C}\right]$ acetate incorporation into lipid in 3T3 L1 adipocytes (Price et al., 1986). To examine whether this is true in vivo, the lipogenic rate was measured with ${ }^{3} \mathrm{H}_{2} \mathrm{O}$ in white and brown adipose tissues, liver and carcass of virgin rats after interleukin- 1 administration and oral glucose. There were no significant differences in the lipogenic rate of these tissues between the control and interleukin-1treated animals (Table 4). Lipogenesis was not measured in the lactating group, because food availability modulates mammary-gland lipogenesis (Williamson et al., 1983) and the decreased intestinal absorption observed after interleukin-1 treatment might influence the lipogenic rate of the mammary tissue in vivo (Mercer
Table 4. Effects of interleukin-1 on tissue lipogenesis in virgin rats

The results are mean values \pm S.E.M. for five rats in each group, expressed as $\mu \mathrm{mol}$ of ${ }^{3} \mathrm{H}_{2} \mathrm{O}$ incorporated into saponified lipid/h per $\mathrm{g}$ wet wt. of tissue. For further details see the Experimental section.

\begin{tabular}{lcc}
\hline & \multicolumn{2}{c}{$\begin{array}{c}\text { Rate of lipogenesis } \\
(\mu \text { mol/h per } \mathrm{g})\end{array}$} \\
\cline { 2 - 3 } Tissue & Control & Interleukin-1 \\
\hline Carcass & $3.19 \pm 0.44$ & $3.53 \pm 0.38$ \\
Liver & $17.3 \pm 5.1$ & $19.9 \pm 5.3$ \\
White adipose tissue & $8.40 \pm 3.4$ & $6.82 \pm 1.1$ \\
Brown adipose tissue & $105.3 \pm 24.1$ & $90.2 \pm 31.2$ \\
\hline
\end{tabular}

\& Williamson, 1987) and be confused with an effect of the cytokine.

\section{Blood metabolites and plasma insulin}

Interleukin-1 administration caused a tendency to hypoglycaemia in all experimental groups, but this was only significant in the lactating group (Table 5). Blood lactate concentrations were not altered by interleukin-1 treatment. Interleukin-1 tended to increase plasma insulin concentrations, leading to an increase in the insulin/ glucose ratio, but this was only significant in the virgin group. The effects in vitro of interleukin-1 on insulin secretion from isolated rat pancreatic islets are variable, both inhibition and stimulation occurring depending on the experimental conditions (Comens et al., 1987). The maintenance plasma insulin in the interleukin-1-treated rats suggests that changes in the concentration of the 
Table 5. Effects of interleukin-1 on blood glucose and lactate, and on plasma insulin in fed, virgin, lactating and litterremoved rats

For full details see the Experimental section. The results are mean values \pm S.E.M. for five rats, expressed as $\mu \mathrm{mol} / \mathrm{ml}$ of blood. For the calculation of insulin/glucose ratios, insulin was expressed as $\mu$ units $/ \mathrm{ml}$ of plasma. Values that are significantly different by Student's $t$ test from control values are indicated by ${ }^{*} P<0.05,{ }^{* * *} P<0.001$.

\begin{tabular}{lccc}
\hline & \multicolumn{2}{c}{$\begin{array}{c}\text { Blood metabolite } \\
(\mu \mathrm{mol} / \mathrm{ml})\end{array}$} & $\begin{array}{c}\text { Insulin/ } \\
\text { glucose } \\
\text { ratio }\end{array}$ \\
\cline { 2 - 3 } State of rats & \multicolumn{1}{c}{ Glucose } & Lactate & \\
\hline Virgin & & & \\
$\quad$ Control & $6.75 \pm 0.38$ & $2.21 \pm 0.12$ & $5.1 \pm 0.9$ \\
$\quad$ Interleukin-1 & $5.55 \pm 0.55$ & $2.75 \pm 0.42$ & $11.6 \pm 2.9^{*}$ \\
Lactating & & & \\
$\quad$ Control & $5.50 \pm 0.14$ & $3.51 \pm 0.65$ & $2.0 \pm 0.3$ \\
$\quad$ Interleukin-1 & $4.33 \pm 0.11^{* * *}$ & $3.96 \pm 0.68$ & $3.2 \pm 0.5$ \\
Litter-removed & & & \\
$\quad$ Control & $6.20 \pm 0.41$ & $4.03 \pm 0.31$ & $8.8 \pm 2.4$ \\
Interleukin-1 & $5.00 \pm 0.35$ & $3.50 \pm 0.26$ & $11.0 \pm 2.0$ \\
\hline
\end{tabular}

hormone are not involved in the alterations in tissue lipid accumulation (see Oller do Nascimento \& Williamson, 1988).

\section{Comparison of effects of interleukin-1, tumour necrosis factor- $\alpha$ and tumour growth}

The present results and those of previous studies from this laboratory (Evans \& Williamson, 1988a,b) allow a comparison to be made of the effects in vivo on lipid metabolism of the two related cytokines, interleukin-1 and tumour necrosis factor- $\alpha$ (cachectin), and of tumour growth (Table 6). However, such comparisons must be viewed with some caution, because the dose of tumour necrosis factor was approx. 8-fold higher than that of interleukin-1, and the cytokines were only studied in the acute situation, whereas tumour burden was present for 8-10 days. The two cytokines had very similar effects on lipid metabolism, including decreased absorption, decreased oxidation, decreased deposition in white and brown adipose tissue and lactating mammary gland of an oral lipid load, and hypertriglyceridaemia. The major difference was that there was no significant decrease in measured lipoprotein lipase activity in interleukin-1treated rats, although the effects on lipid metabolism of the cytokine suggested an impairment of the functional enzyme activity. The similarity of the effects of interleukin-1 and tumour necrosis factor on lipid metabolism (Table 6) suggest that they may act in concert in vivo. This view is strengthened by the finding that tumour necrosis factor can stimulate interleukin-1 secretion in vivo and in vitro (Bachwich et al., 1986; Dinarello et al., 1986). The reverse is also true (Nawroth et al., 1986). In contrast with the two cytokines, tumour growth itself did not alter lipid absorption or lipid accumulation in the lactating mammary gland (Evans \& Williamson, $1988 a$ ); the effects on lipid metabolism appeared to be restricted to adipose tissue (Table 6). This explains the absence of hypertriglyceridaemia in tumour-bearing lactating rats (Evans \& Williamson, 1988a), because lipid
Table 6. Comparison of the effects of interleukin-1, tumour necrosis factor or tumour growth on exogenous $\left[{ }^{14}\right.$ Cllipid metabolism in the rat

The information in this Table was compiled from the results in the present paper and in those of Evans \& Williamson $(1988 a, b)$. The changes are relative to control (virgin, lactating or litter-removed) rats.

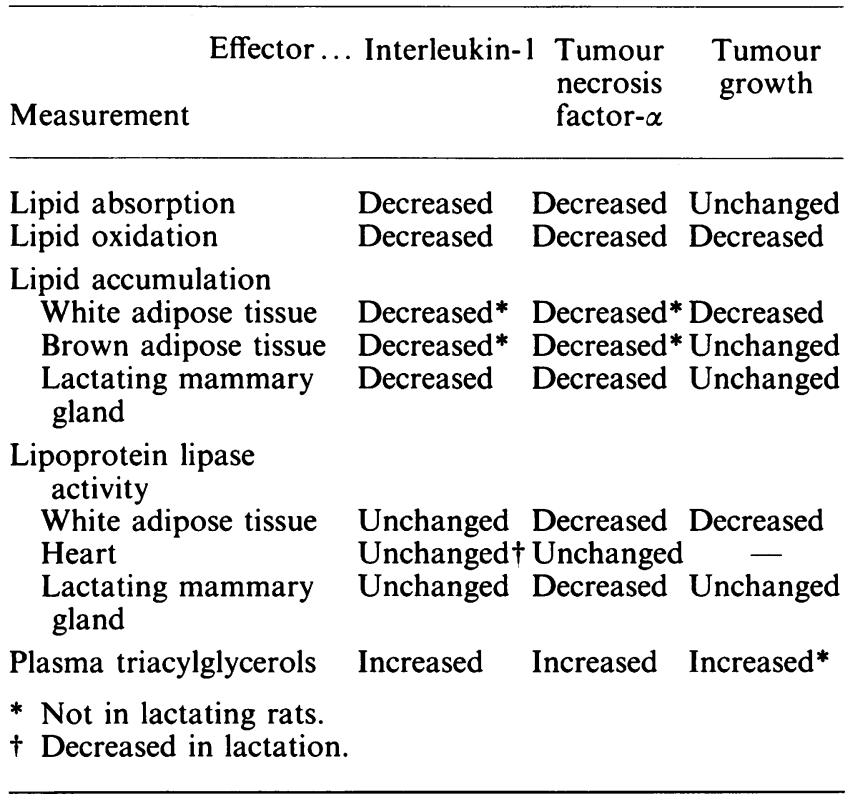

deposition is depressed in adipose tissue and enhanced in mammary gland during lactation (Oller do Nascimento $\&$ Williamson, 1986). Thus tumour growth, at least in the case of the Walker 256 carcinoma, appears to be more tissue-specific in its actions on lipid metabolism, which suggests that factors other than tumour necrosis factor or interleukin-1 may be involved in its effects.

We thank Mrs. Vera Ilic for skilled assistance and Mrs. M. Barber for preparation of the typescript. F.J.L.-S. held a Unilever Short-Term Fellowship from the Biochemical Society. J.M.A. was supported by grants from the CIRIT (Generalitat de Catalunya) and the Spanish Ministry of Education. R.D.E. holds an M.R.C. Training Fellowship, and D.H.W. is a member of the M.R.C. External Scientific Staff.

\section{REFERENCES}

Agius, L. \& Williamson, D. H. (1980) Biochem. J. 190, 477-480 Agius, L., Robinson, A. M., Girard, J. R. \& Williamson, D. H. (1979) Biochem. J. 180, 689-692

Albano, J. D. M., Ekins, R. P., Maritz, G. \& Turner, R. C. (1972) Acta Endocrinol. (Copenhagen) 70, 487-509

Bachwich, P. R., Chensue, S. W., Larrick, J. W. \& Kunkel, S. L. (1986) Biochem. Biophys. Res. Commun. 136, 94-101 Baracos, V., Rodemann, H. P., Dinarello, C. A. \& Goldberg, A. L. (1983) N. Engl. J. Med. 308, 553-558

Comens, P. G., Wolf, B. A., Unanue, E. R., Lacy, P. E. \& McDaniel, M. L. (1987) Diabetes 36, 963-970

Dinarello, C. A. (1984) N. Engl. J. Med. 311, 1413-1418

Dinarello, C. A. \& Wolff, S. M. (1982) Am. J. Med. 72, 799-819

Dinarello, C. A., Cannon, J. G., Wolff, S. M., Bernheim, H. A., Beutler, B., Cerami, A., Figari, I. S., Palladino, M. A., Jr. \& O'Connor, J. V. (1986) J. Exp. Med. 163, 1433-1450

Eggstein, M. \& Kreutz, F. H. (1966) Klin. Wochenschr. 44, 262-267 
Evans, R. D. \& Williamson, D. H. (1988a) Biochem. J. 252, 65-72

Evans, R. D. \& Williamson, D. H. (1988b) Biochem. J. 256, 1055-1058

Falkoff, R. J. M., Muraguchi, A., Hong, J. X., Butler, J. L., Dinarello, C. A. \& Fauci, A. S. (1983) J. Immunol. 131, 801-805

Flint, D. J., Clegg, R. A. \& Vernon, R. G. (1981) Mol. Cell. Endocrinol. 22, 265-275

Garland, P. B. \& Randle, P. J. (1962) Nature (London) 196, 987-988

Hamosh, M., Clary, T. R., Chernick, S. S. \& Scow, R. O. (1970) Biochim. Biophys. Acta 210, 473-482

Hohorst, H. J. (1963) in Methods of Enzymatic Analysis (Bergmeyer, H. U., ed.), pp. 215-219, Academic Press, New York and London

Kampschmidt, R. F. (1984) Lymphokine Res. 2, 97-110

Kuwajima, M., Foster, D. W. \& McGarry, J. D. (1988) Metab. Clin. Exp. 37, 597-601

Mizel, S. B. (1982) Immunol. Rev. 63, 51-72

Mercer, S. W. \& Williamson, D. H. (1987) Biochem. J. 242, 235-243

Nawroth, P. P., Bank, I., Handley, D., Cassimeris, J., Chess, L. \& Stern, D. (1986) J. Exp. Med. 163, 1363-1375

Nilsson-Ehle, P. \& Ekman, R. (1977) Artery 3, 197-209

Nilsson-Ehle, P. \& Schotz, M. C. (1976) J. Lipid Res. 17, 536-541
Oller do Nascimento, C. M. \& Williamson, D. H. (1986) Biochem. J. 239, 233-236

Oller do Nascimento, C. M. \& Williamson, D. H. (1988) Biochem. J. 254, 539-546

Patton, J. S., Peters, P. M., McCabe, J., Crase, D., Hansen, S., Chen, A. B. \& Liggitt, D. (1987) J. Clin. Invest. 80, 1587-1596

Pepys, M. B. \& Baltz, M. L. (1983) Adv. Immunol. 34, 141-212

Price, S. R., Mizel, S. B. \& Pekala, P. H. (1986) Biochim. Biophys. Acta 889, 374-381

Robinson, D. S. (1970) Compr. Biochem. 18, 51-116

Robinson, A. M., Girard, J. R. \& Williamson, D. H. (1978) Biochem. J. 176, 343-346

Scow, R. O. \& Chernick, S. S. (1987) in Lipoprotein Lipase (Borensztajn, J., ed.), pp. 149-185, Evener Publishers, Chicago

Slein, M. W. (1963) in Methods of Enzymatic Analysis (Bergmeyer, H. U., ed.), pp. 117-123, Academic Press, New York and London

Stansbie, D., Brownsey, R. W., Crettaz, M. \& Denton, R. M. (1976) Biochem. J. 160, 413-416

Vernon, R. G. \& Flint, D. J. (1983) Proc. Nutr. Soc. 42, 315-331

Williamson, D. H. (1980) FEBS Lett. 117 (Suppl.), K93-K 105

Williamson, D. H. (1986) Reprod. Nutr. Dev. 26, 597-603

Williamson, D. H., Munday, M. R., Jones, R. G., Roberts, A. F. C. \& Ramsey, A. J. (1983) Adv. Enzyme Regul. 21, $135-145$ 